Harmful Algae

March 2016, Volume 53 Pages 1-7

http://dx.doi.org/10.1016/j.hal.2015.11.005

http://archimer.ifremer.fr/doc/00333/44435/

(c) 2015 Elsevier B.V. All rights reserved.

\title{
Forecasting the risk of harmful algal blooms
}

\author{
Davidson Keith ${ }^{1,{ }^{*}}$, Anderson Donald M. ${ }^{2}$, Mateus Marcos ${ }^{3}$, Reguera Beatriz ${ }^{4}$, Silke Joe ${ }^{5}$, \\ Sourisseau Marc ${ }^{6}$, Maguire Julie ${ }^{7}$
}

${ }^{1}$ Scottish Assoc Marine Sci, Scottish Marine Inst, Oban PA37 1QA, Argyll, Scotland.

${ }^{2}$ Woods Hole Oceanog Inst, Woods Hole, MA 02543 USA.

${ }^{3}$ Univ Lisbon, Inst Super Tecn, MARETEC, Ave Rovisco Pais, P-1049001 Lisbon, Portugal.

${ }^{4}$ IEO, Subida Radio Faro 50, Vigo 36390, Spain.

${ }^{5}$ Inst Marine, Oranmore, Galway, Ireland.

${ }^{6}$ IFREMER, Lab Ecol Pelag, Ctr Bretagne, ZI Pointe Diable,CS 10070, F-29280 Plouzane, France.

${ }^{7}$ Daithi OMurchu Marine Res Stn, Bantry, Cork, Ireland.

* Corresponding author : Keith Davidson, email address : Keith.Davidson@sams.ac.uk

\begin{abstract}
:
The "Applied Simulations and Integrated Modelling for the Understanding of Harmful Algal Blooms" (Asimuth) project sought to develop a harmful algal bloom (HAB) alert system for Atlantic Europe. This was approached by combining, at a national or regional level, regulatory monitoring phytoplankton and biotoxin data with satellite remote sensing and other information on current marine conditions, coupled with regional scale models that included a representation of HAB transport. Synthesis of these products was achieved by expert interpretation within HAB risk alert bulletins that were prepared on a regular basis (typically weekly) for use by the aquaculture industry. In this preface to the Asimuth Special Issue we outline the main HAB species of concern in the region and the strengths and limitations of different methodologies to provide early warning of their blooms.
\end{abstract}




\section{Introduction}

Early warning of the timing, location and magnitude of harmful algal blooms (HABs) is potentially of great value to coastal zone managers and the aquaculture industry, informing business planning and ensuring the protection of human health. Achieving this goal is, however, far from straightforward as key HAB genera or species exhibit different life cycles and potentially variable toxicity. Variability in local or regional oceanography or hydrography is also critical to bloom location and timing.

High biomass blooms may disrupt wild fisheries or mariculture through physical interference, de-oxygenation or toxicity (Brand et al., 2012). In contrast, low biomass producers of biotoxins are of particular concern to shellfish aquaculture, as there is potential for significant impact on human health through consumption of shellfish that have bio-accumulated toxin within their flesh (Davidson and Bresnan, 2009). HABs may also have a direct impact on humans though aerosol transfer of toxin and disruption to recreational activities on beaches (Fleming et al., 2011).

The studies presented in this Special Issue focus on research in the Western European waters of Portugal, Spain, France, Ireland and Scotland (Figure 1) as part of the EU FP7 programme: Applied Simulations and Integrated Modelling for the Understanding of Toxic and Harmful Algal Blooms "Asimuth". Asimuth sought to produce national or regional HAB forecasting systems, by combining national monitoring program and satellite remote sensing data streams with regional scale HAB transport models. Expert interpretation was then employed to generate an estimated HAB risk that was disseminated to stakeholders though alert bulletins.

\section{Phytoplankton monitoring as early warning}

Many countries operate monitoring programmes for the presence of harmful algae. Most frequently these are aimed at ensuring shellfish safety, and in Europe such programmes are a requirement of EU shellfish hygiene directives. In practice, monitoring methodology varies by country (Anderson, 1996), but in all cases these time series data sets provide a short-term early warning of risk. Regulators often use HAB data to trigger toxicity testing, i.e. when elevated cell counts of the causative phytoplankton are encountered. Regulatory data are typically made freely available on the internet and hence may provide short-term warning to aquaculturalists of the occurrence of harmful species and the subsequent potential for associated shellfish toxins or fish kills.

\section{Advective HABs in the Asimuth region}


Many HAB organisms can be transported significant distances in shelf waters by currents (Farrell et al., 2012; Anderson et al., 2005). In some locations there are known persistent advective mechanisms which result in the transfer of phytoplankton along the coast or from offshore frontal boundaries, providing the potential for regional predictions (e.g., the Maine coastal current system and Alexandrium blooms in the northeastern US (Anderson et al. 2005a; McGillicuddy et al. 2011) and alongshore transport of Dinophysis blooms in northwest Spain at the end of the upwelling season (Escalera et al., 2010). Knowledge of the Baltic current was important in warning Norwegian fish farmers of the 1998 major fish killing Chrysochromulina bloom (Dahl et al., 2005). In such cases, there is the potential to give considerable advance warning of where bloom events may occur.

For advective blooms the increase in density at an aquaculture site may be more rapid than would be assumed from in situ growth alone, the cells being concentrated by physical as well as biological factors (e.g., convergences, onshore winds, vertical migration). As the frequency of monitoring is typically no more than weekly, early HAB warning may not always be achievable from phytoplankton time series data. For example Figure 2 shows that the increase in Dinophysis and the associated shellfish toxicity (that resulted in a major shellfish poisoning incident) occurred with a lag of less than a week at Seggi bight in the Scottish Shetland Isles in 2013. This event was a result of cross shelf advection of the harmful bloom (Whyte et al., 2014). It is these advective HAB blooms, that are difficult to predict from in situ monitoring alone, and on which Asimuth concentrated its effort.

\section{Western European HABs}

In Western Europe the main shellfish toxin producing phytoplankton are members of the genera Alexandrium, Dinophysis, Pseudo-nitzschia and Azadinium along with the species Gymnodinium catenatum.

Azadinium and its toxin azaspiracid were relatively recently identified (Tillmann et al., 2009), its life cycle remains uncertain, and it small size makes it difficult to monitor by microscopy. All of these factors limit current capacity to develop an alert system for it and its associated toxins.

While the potent paralytic shellfish poisoning (PSP) causative genera Alexandrium is present in Western Europe, in contrast to locations such as the Gulf of Maine in which large scale advection of $A$. fundyense occurs annually (see below), its impact in Europe is most often within semi-enclosed regions of restricted exchange. Examples include A. minutum in the Penze estuary Northern France (Chapelle et al., 2010), in Cork Harbour Ireland (Touzet et al., 2007) and in a small embayment within Ría de Vigo (Bravo et al., 2010), A catanella in the Thau Lagoon Southern France (Collos et al., 2007), and A. tamarense in the fjordic sea lochs of Scotland (Touzet et al., 2010). Blooms typically appear when 
conditions are suitable to promote excystment of cells from the sediment. While the (typically) localised appearance of this organism in Europe offers the potential of some degree of early warning of shellfish toxicity based on cell counts (e.g. Figure 1), it also indicates Alexandrium is best modelled at a local scale. An example of a location where such an approach is applied is Cork Harbour, Ireland (Ní Rathaille and Raine, 2011). Better physiological understanding of Alexandrium growth in different conditions is required to improve such models.

The remaining major Western European biotoxic HAB organisms (Dinophysis, Pseudonitzschia, Gymnodinium catenautm) have the potential to be advected to/along coastlines and hence require a larger scale approach. These organisms either do not have a cyst or spore stage, or if they do (e.g., G. catenatum), that resting state has a very short mandatory dormancy that allows rapid recolonization of the water column. Localized cyst or spore seedbeds are thus less important in the dynamics of these HABs than persistent planktonic populations of these species, including mobile planozygotes germination with no need their previous maturation into hypnozygotes (Escalera and Reguera, 2008; Figueroa et al., 2008). Similarly the ichthyotoxic Karenia mikimotoi (another non-cystformer) is apparently increasingly prevalent in western European waters having been observed at bloom densities frequently in recent years with offshore development and advective transport being evident (Bresnan et al., 2010; Davidson et al., 2009).

\section{Remote sensing}

In offshore environments, where advective HABs often initiate, difficulties in obtaining regular samples means that potentially harmful phytoplankton cannot be directly monitored in a routine, easy or cost effective manner. Remote sensing offers a potential solution to this, and may be conducted either by satellite or through the deployment of in situ sensors of HAB species or their toxins. A number of factors limit the effectiveness of this approach.

Satellite earth observation of ocean colour provides an estimate of chlorophyll concentration in near surface waters (up to 20-25 $\mathrm{m}$ in the clearest of waters (Kemp and Villareal, 2013)), although the availability of information is limited by clouds. The reliance on chlorophyll makes this information most valuable when biomass is high, with applications including red tides in Ariake Sound Japan (Ishizaka et al., 2006) and Pseudo-nitzschia blooms in the Galician Rías, Spain (Spyrakos et al., 2011).

Development of algorithms for the specific detection and classification of harmful species from satellite data is on-going, an example being the Florida bloom index of the red tide organism Karenia brevis (Amin et al., 2009). A similar approach has been taken in Europe, based on parameters such as absorption, total backscatter, and water-leaving radiance for K. mikimotoi, but further development will 
be required to make such systems operational (Shutler et al., 2012), and application to other, less easily characterised HAB organisms, will be challenging. Drawbacks of remote sensing are that, in general, some degree of in situ validation is required to verify the composition of a remotely detected bloom, and the methods are inadequate to identify sub-surface or low biomass blooms of, for example, Dinophysis spp. (Moita et al., 2006) which do not often reach densities above $10^{4}$ cells $1^{-1}$.

In situ sensors overcome some of the limitations of satellite systems, but lack spatial resolution, and their deployment often comes at significant cost. In certain situations such an approach has addressed the need for species-specific identification and enumeration. K. brevis produces a pigment, gyroxanthin-diester, that is sufficiently distinct to be biomarker within the Gulf of Mexico region (Richardson and Pinckney, 2004). Instruments have therefore been developed allowing its quantification from research vessels (Kirkpatrick et al., 2003) and using autonomous underwater vehicles (AUVs) or moorings (Campbell et al., 2013). This approach has great potential for monitoring HAB organisms that have unique pigmentations, but for the majority of HAB species that are not so readily characterised, alternative approaches to automated detection are needed.

An alternative in situ approach utilizes species- or strain-specific molecular "probes" that can label HAB cells of interest so they can be detected visually, electronically, or chemically. Probes and assays of multiple types are now available for many of the HAB species, with molecular counting methods being routinely employed in major research programs, e.g. Anderson et al. (2005b). Application in monitoring programmes, while not unknown (Rhodes et al., 2013), is less prevalent due to issues of probe specificity, cost, and the difficulty of using fixatives in the field.

While still somewhat developmental, at least in terms of their routine application, these cell detection technologies open the door to an era where remote, sub-surface, near real-time detection of specific HAB taxa can be envisioned. An early example of such technology is the Environmental Sampling Processor (ESP); (Scholin et al., 2009) that autonomously collects discrete water samples and automates application of molecular probes to identify specific organisms.

\section{Modelling methodology}

McGillicuddy (2010) reviewed many numerical modelling developments related to HABs. It is therefore not our intention to further review such HAB modelling studies here, but rather to identify a range of modelling methodologies and their strengths and weaknesses within an alert system, through a range of examples below.

Risk assessment style models 
Such models are empirical in nature and typically relatively simple computationally, inferring cause-and-effect relationship between a HAB and its environment to a few key parameters or thresholds. Geographical areas that have well understood weather patterns and physical oceanography are most amenable to this approach. An early example for the Galicia Rías (NW Spain) was presented by (Fraga et al., 1988) with relaxation of upwelling at the end of the upwelling season having been demonstrated to result in the transport of offshore populations of Gymnodinium catenatum into the rías.

A further example relates to blooms of Dinophysis and resulting shellfish toxicity in the bays of southwest of Ireland (Raine et al., 2010). A wind-driven two-layer oscillatory flow exchanges a proportion of the bays' volumes, and HAB events arise with the associated transport of harmful populations into them. Development of this approach is presented by Dabrowski et al. (this issue). Lagrangian models

When blooms form offshore and are transported to the coast by oceanographic conditions, lagrangian models that simulate the passive transport of particles are a potential option for HAB early warning. These models do not incorporate the processes of biological growth or decay of a bloom, and are hence suitable when physical processes dominate over biological ones. Such an approach was used to simulate a Dinophysis acuminata bloom off the Brittany coast, with physical processes of dispersion alone being capable of explaining its decay (Velo-Suárez et al., 2010).

\section{Ecosystem based models}

These coupled physical/biological models are typically Eulerian in nature, calculating biological variables at fixed locations in space, with these variables being subject to physical (advection, diffusion) and biological processes (growth, mortality etc). Prediction is achieved by solving equations on a grid lattice. Many recent developments in this field of modelling have related to the prediction of climate change on phytoplankton aggregated as single or multiple functional groups. Their ability to simulate HABs was reviewed by (Allen et al., 2008) with particular reference to high biomass blooms in eutrophic coastal waters. While such models were found to have some skill in predicting blooms, it is clear that those that depict phytoplankton to functional group only rarely have the capacity to make accurate forecasts of even high biomass HABs. Examples that have had some success (e.g. Lacroix et al., 2007; Vanhoutte-Brunier et al., 2008) have extended an existing ecosystem model framework to specifically incorporate high biomass organisms of interest. Individual based models

Alternative and promising computational modelling approaches combine a physical model with an individual based model (IBM) that considers only the specific organism of interest. IBM models calculate biological variables while following individual (or meta-) particles in space. Model (virtual) 
particles represent a cohort (typically billions) of cells. Particles, that may hold biological properties, are subject to advection and diffusion and their position is tracked around the model domain.

Statistical models

Statistically based models synthesise the measured relationships between phytoplankton abundance and potentially causative environmental conditions. Recent examples of this approach relate to Pseudo-nitzschia with Anderson et al. (2009) applying linear hindcasting to determine the environmental conditions associated with Pseudo-nitzschia spp. blooms in the Santa Barbara Channel, and both (Lane et al., 2009) and (Anderson et al., 2010) using logistic regression, to hindcast of Pseudo-nitzschia blooms in Monterey Bay and Chesapeake Bay respectively. While providing insight into bloom dynamics, the difficulty in obtaining real time information on the predictive environmental conditions can makes these models difficult to apply in forecast mode.

\section{Coupled Observational-Modelling Systems}

Operational coupled observational/modelling HAB prediction systems, while few in number, do exist. The NOAA harmful algal bloom operational forecast (HAB-OFS) that operates in Florida and Texas in the US (Stumpf et al., 2008). This system relies on a number of the approached discussed above including satellite imagery, field observations and mathematical models. It also incorporates public health reports and buoy data to predict blooms and their movement. It is, however, limited to mono-specific high biomass blooms that are detectable from satellites using ocean colour algorithms, and the actual forecasts are based on passive particle transport

A further successful example is Coastal waters of the northeastern United States are subject to annually recurring PSP events caused by Alexandrium fundyense blooms that are transported in a generally south-westerly direction along the coast by coastal current advection, with wind driven forcing being capable of moving surface waters, and their associated HAB populations, both onshore and offshore. These competing transport mechanisms make prediction of the timing and magnitude of any coastal bloom difficult to determine by observation alone. A coupled physical/biological model that includes a representation of both a resting cyst and a vegetative cell (Anderson, 1998) is therefore employed to predict the development and transport of the bloom (McGillicuddy et al., 2005). The model comprises a Regional Ocean Modeling System (ROMS) approach with a coupled biological submodel that represents the timing and rates of cyst germination and cell growth. The model is initialised based on detailed knowledge of the distribution of $A$. fundayense cysts in the region prior to each growth season. This information is gathered by ship based surveys (Anderson et al., 2014). The model has been successfully used for hindcasts (Li et al., 2009) and is now being used to issue weekly nowcasts and forecasts, and even seasonal or annual forecasts (McGillicuddy et al., 2011), Figure 3. 


\section{Conclusion}

A range of methods and technologies are available to provide HAB early warning. Risk assessment based on any one of these is fraught with uncertainties. In Western Europe the building blocks of multi-parameter warning systems exist, with a relatively few organisms of concern, welldeveloped shellfish biotoxin and plankton monitoring programmes, the availability of satellite based remote sensing data, and pre-existing hydrodynamic, and for some HAB genera, biological models.

The goal of the Asimuth was therefore, for the first time, to produce a coherent HAB early warning system for the western European seaboard. Given that the HABs of primary concern differ from country to country, as do the format of national regulatory monitoring programmes and the hydrodynamic models available, a fully integrated region-wide alert system was not practicable, nor desirable. Neither did we seek to directly recreate those alert systems that are operational elsewhere, as again, the organisms, hydrography and available infrastructure differ too much. Rather, national systems were formulated based on local or regional needs. These were designed, however, to be compatible, allowing easy transfer of information and approaches from one region to another.

In the papers that follow we describe some of the developments in HAB risk assessment that took place within Asimuth in Portugal (Moita et al.; Pinto et al.; Silva et al.), Spain (Díaz et al.; RuizVillarreal et al.;), France (Soutisseau et al.), Ireland (Cusack et al.;Dabrowski et al.; O’Boyle et al.), and Scotland (Aleynik et al.; Eckford-Soper et al.; Gillibrand et al.;). In the associated conclusions paper (Maguire et al.) we summarise the findings of these studies and describe their use in the different national/regional forecasting systems developed during the project.

\section{Acknowledgements}

The Asimuth project was supported by the EU FP7 Programme, Space Theme, Grant Agreement No.: 261860. Support for DMA was provided by the Woods Hole Center for Oceans and Human Health, National Science Foundation Grant (OCE-1314642) and National Institute of Environmental Health Sciences Grant (1-P01-ES021923-01). Data for Figure 2 was generated as part of the Food Standards Agency official control monitoring for Scottish waters (contract code FS513005). 


\section{References}

Allen, J.I., Smyth, T.J., Siddorn, J.R., Holt, M., 2008. How well can we forecast high biomass algal bloom events in a eutrophic coastal sea? Harmful Algae 8, 70-76. doi:10.1016/j.hal.2008.08.024

Amin R, Zhou, J., Gilerson, A., Gross, B., Moshart, F., Ahmed, S., 2009. Novel Optical Techniques for Detecting and Classifying Toxic Dinoflagellate Karenia Brevis Blooms Using Satellite Imagery. Opt. Express 17, 9126-9144.

Anderson, C., Siegel, D., Kudela, R., Brzezinski, M., 2009. Empirical models of toxigenic Pseudonitzschia blooms: Potential use as a remote detection tool in the Santa Barbara Channel. Harmful Algae 8, 478-492. doi:10.1016/j.hal.2008.10.005

Anderson, C.R., Sapiano, M.R.P., Prasad, M.B.K., Long, W., Tango, P.J., Brown, C.W., Murtugudde, R., 2010. Predicting potentially toxigenic Pseudo-nitzschia blooms in the Chesapeake Bay. J. Mar. Syst. 83, 127-140. doi:10.1016/j.jmarsys.2010.04.003

Anderson, D., Townsend, D.W., McGillicuddy, D.J., JT, T., 2005. The Ecology and Oceanography of Toxic Alexandrium fundyense Blooms in the Gulf of Maine. Deep Sea Res. Part II Top. Stud. Oceanogr. 52, 2365-2876.

Anderson, D.M., 1998. Physiology and bloom dynamics of toxic Alexandrium species, with emphasis on life cycle transitions, in: Anderson, D.M., Cembella, A.D., Hallegraeff, G. (Eds.), The Physiological Ecology of Harmful Algal Blooms. Springer-Verlag, Heidelberg, pp. 29-48.

Anderson, D.M., Keafer, B.A., Kleindinst, J.L., McGillicuddy, D.J., Martin, J.L., Norton, K., Pilskaln, C.H., Smith, J.L., Sherwood, C.R., Butman, B., 2014. Alexandrium fundyense cysts in the Gulf of Maine: Long-term time series of abundance and distribution, and linkages to past and future blooms. Deep. Res. Part II Top. Stud. Oceanogr. 103, 6-26. doi:10.1016/j.dsr2.2013.10.002

Anderson, D.M., Kulis, D.M., Keafer, B.A., Gribble, K.E., Marin, R., Scholin, C.A., 2005a. Identification and enumeration of Alexandrium spp. from the Gulf of Maine using molecular probes. Deep Sea Res. Part II Top. Stud. Oceanogr. 52, 2467-2490.

doi:10.1016/j.dsr2.2005.06.015

Anderson, D.M., Stock, C.A., Keafer, B.A., Bronzino Nelson, A., Thompson, B., McGillicuddy, D.J., Keller, M., Matrai, P.A., Martin, J., 2005b. Alexandrium fundyense cyst dynamics in the Gulf of Maine. Deep Sea Res. Part II Top. Stud. Oceanogr. 52, 2522-2542.

doi:10.1016/j.dsr2.2005.06.014

Anderson, P., 1996. Design and Implementation of some Harmful Algal Monitoring Systems.

Brand, L.E., Campbell, L., Bresnan, E., 2012. Karenia: The biology and ecology of a toxic genus. Harmful Algae 14, 156-178. doi:10.1016/j.hal.2011.10.020

Bravo, I., Isabel Figueroa, R., Garcés, E., Fraga, S., Massanet, A., 2010. The intricacies of dinoflagellate pellicle cysts: The example of Alexandrium minutum cysts from a bloom-recurrent 
area (Bay of Baiona, NW Spain). Deep Sea Res. Part II Top. Stud. Oceanogr. 57, 166-174. doi:10.1016/j.dsr2.2009.09.003

Bresnan, E., Fernand, L., Davidson, K., Edwards, M.E., Millligan, S.M., Gowan, R.G., Silke, J., S, K., Raine, R., 2010. Climate Change impacts on Harmful Algal Blooms (HABs), in: MCCIP Annual Report Card 2010-11, MCCIP Science Review. p. 10pp.

Campbell, L., Henrichs, D.W., Olson, R.J., Sosik, H.M., 2013. Continuous automated imaging-in-flow cytometry for detection and early warning of Karenia brevis blooms in the Gulf of Mexico. Environ. Sci. Pollut. Res. Int. 20, 6896-902. doi:10.1007/s11356-012-1437-4

Chapelle, A., Labry, C., Sourisseau, M., Lebreton, C., Youenou, A., Crassous, P., Pelagos, I.D., Gkss, F., 2010. Alexadnrium minutum growth controlled by phosphorous: An applied model. J Mar. Syst. 83, 181-191.

Collos, Y., Vaquer, A., Laabir, M., Abadie, E., Laugier, T., Pastoureaud, A., Souchu, P., 2007. Contribution of several nitrogen sources to growth of Alexandrium catenella during blooms in Thau lagoon, southern France. Harmful Algae 6, 781-789. doi:10.1016/j.hal.2007.04.003

Dahl, E., Bagøien, E., Edvardsen, B., Stenseth, N.C., 2005. The dynamics of Chrysochromulina species in the Skagerrak in relation to environmental conditions. J. Sea Res. 54, 15-24. doi:10.1016/j.seares.2005.02.004

Davidson, K., Bresnan, E., 2009. Shellfish toxicity in UK waters: a threat to human health? Environ. Health 8 Suppl 1, S12. doi:10.1186/1476-069X-8-S1-S12

Davidson, K., Gowen, R.J., Tett, P., Bresnan, E., Harrison, P.J., Mckinney, A., Milligan, S., Mills, D.K., Silke, J., Crooks, A., 2012. Harmful algal blooms : How strong is the evidence that nutrient ratios and forms influence their occurrence? Estuar. Coast. Mar. Sci. 115, 399-413.

Davidson, K., Miller, P., Wilding, T.A., Shutler, J., Bresnan, E., Kennington, K., Swan, S., 2009. A large and prolonged bloom of Karenia mikimotoi in Scottish waters in 2006. Harmful Algae 8, 349-361. doi:10.1016/j.hal.2008.07.007

Escalera, L., Reguera, B., 2008. Planozygote division and other observations on the sexual cycle of several species of Dinophysis (Dinophyceae, Dinophysiales). J. Phycol. 44, 1425-1436. doi:10.1111/j.1529-8817.2008.00610.x

Escalera, L., Reguera, B., Moita, T., Pazos, Y., Cerejo, M., Cabanas, J.M., Ruiz-Villarreal, M., 2010. Bloom dynamics of Dinophysis acuta in an upwelling system: In situ growth versus transport. Harmful Algae 9, 312-322. doi:10.1016/j.hal.2009.12.002

Farrell, H., Gentien, P., Fernand, L., Lunven, M., Reguera, B., González-Gil, S., Raine, R., 2012. Scales characterising a high density thin layer of Dinophysis acuta Ehrenberg and its transport within a coastal jet. Harmful Algae 15, 36-46. doi:10.1016/j.hal.2011.11.003

Figueroa, R.I., Bravo, I., Garcés, E., 2008. The significance of sexual versus asexual cyst formation in the life cycle of the noxious dinoflagellate Alexandrium peruvianum. Harmful Algae 7, 653-663. doi:10.1016/j.hal.2008.02.005 
Fleming, L.E., Kirkpatrick, B., Backer, L.C., Walsh, C.J., Nierenberg, K., Clark, J., Reich, A., Hollenbeck, J., Benson, J., Cheng, Y.S., Naar, J., Pierce, R., Bourdelais, A.J., Abraham, W.M., Kirkpatrick, G., Zaias, J., Wanner, A., Mendes, E., Shalat, S., Hoagland, P., Stephan, W., Bean, J., Watkins, S., Clarke, T., Byrne, M., Baden, D.G., 2011. Review of Florida Red Tide and Human Health Effects. Harmful Algae 10, 224-233. doi:10.1016/j.hal.2010.08.006

Fraga, S., Anderson, D., Bravo, I., 1988. Influence of upwelling relaxation on dinoflagellates and shellfish toxicity in Ria de Vigo, Spain. Estuar. Coast. Shelf Sci. 27, 349-361.

Glibert, P.M., Seitzinger, S.P., Heil, C.A., Burkholder, J.M., Parrow, M.W., Codispoti, L.A., Kelly, V., 2005. The role of eutrophication in the global proliferation of harmful algal blooms.

Oceanography 18, 198-209.

Goffredi, S.K., Jones, W.J., Scholin, C.A., Marin, R., Vrijenhoek, R.C., 2006. Molecular detection of marine invertebrate larvae. Mar. Biotechnol. (NY). 8, 149-60. doi:10.1007/s10126-005-5016-2

Gowen, R.J., Mckinney, A., Tett, P., Bresnan, E., Davidson, K., Harrison, P.J., Milligan, S., Mills, D.K., Silke, J., Crooks, A.M., 2012. Anthropogenic nutrient enrichment and blooms of harmful phytoplankton. Oceanogr. Mar. Biol. 50, 65-126.

Ishizaka, J., Kitaura, Y., Touke, Y., Sasaki, H., Tanaka, A., H, M., T, S., 2006. Satellite detection of red tide in Ariake Sound 1998-2201. J Oceanogr. 62, 37-45.

Kemp, A.E.S., Villareal, T.A., 2013. High diatom production and export in stratified waters - A potential negative feedback to global warming. Prog. Oceanogr. 119, 4-23. doi:10.1016/j.pocean.2013.06.004

Kirkpatrick, G.J., Millie, D., Moline, M.A., Schofield, O., 2000. Optical discrimination of a phytoplankton species in natural mixed populations. Limnol. Oceanogr. 45, 467-471.

Kirkpatrick, G.J., Orrico, C., Moline, M.A., Oliver, M., Schofield, O., 2003. Continuous hyperspectral absorption measurements of coloured dissolved organic material in aquatic systems. Appl. Opt. 42, 6564-6568.

Lacroix, G., Ruddick, K., Park, Y., Gypens, N., Lancelot, C., 2007. Validation of the 3D biogeochemical model MIRO\&CO with field nutrient and phytoplankton data and MERIS-derived surface chlorophyll a images. J. Mar. Syst. 64, 66-88. doi:10.1016/j.jmarsys.2006.01.010

Lane, J., Raimondi, P., Kudela, R., 2009. Development of a logistic regression model for the prediction of toxigenic Pseudo-nitzschia blooms in Monterey Bay, California. Mar. Ecol. Prog. Ser. 383, 3751. doi:10.3354/meps07999

Li, Y., He, R., McGillicuddy, D.J., Anderson, D.M., Keafer, B.A., 2009. Investigation of the 2006 Alexandrium fundyense bloom in the Gulf of Maine: In-situ observations and numerical modeling. Cont. Shelf Res. 29, 2069-2082. doi:10.1016/j.csr.2009.07.012

McGillicuddy, D.J., 2010. Models of harmful algal blooms: Conceptual, empirical, and numerical approaches. J. Mar. Syst. 83, 105-107. doi:10.1016/j.jmarsys.2010.06.008 
McGillicuddy, D.J., Anderson, D.M., Lynch, D.R., Townsend, D.W., 2005. Mechanisms regulating large-scale seasonal fluctuations in Alexandrium fundyense populations in the Gulf of Maine: Results from a physical-biological model. Deep Sea Res. Part II Top. Stud. Oceanogr. 52, 26982714. doi:10.1016/j.dsr2.2005.06.021

McGillicuddy, J., J., D., Townsend, D.W., He, R., Keafer, B.A., Kleindinst, J.L., Li, Y., Manning, J.P., Mountain, D.G., Thomas, M.A., Anderson, D.M., 2011. Suppression of the 2010 Alexandrium fundyense bloom by changes in physical, biological, and chemical properties of the Gulf of Maine. Limnol. Oceanogr. 56, 2411-2426. doi:10.4319/lo.2011.56.6.2411

Moita, M., Sobrinho-Gonçalves, L., Oliveira, P., Palma, S., Falcão, M., 2006. A bloom of Dinophysis acuta in a thin layer off North-West Portugal. African J. Mar. Sci. 28, 265-269. doi:10.2989/18142320609504160

Ní Rathaille, A., Raine, R., 2011. Seasonality in the excystment of Alexandrium minutum and Alexandrium tamarense in Irish coastal waters. Harmful Algae 10, 629-635. doi:10.1016/j.hal.2011.04.015

Raine, R., McDermott, G., Silke, J., Lyons, K., Nolan, G., Cusack, C., 2010. A simple short range model for the prediction of harmful algal events in the bays of southwestern Ireland. J. Mar. Syst. 83, 150-157. doi:10.1016/j.jmarsys.2010.05.001

Rhodes, L., Smith, K., Moisan, C., 2013. Shifts and stasis in marine HAB monitoring in New Zealand. Environ. Sci. Pollut. Res. 20, 6872-6877. doi:10.1007/s11356-012-0898-9

Rhodes, L.L., Scholin, C.A., Tyrell, J., Adamson, J., Todd, K., 2001. The integrations of DNA probes into New Zealand's routine phytoplankton monitoring programmes., in: Hallegraeff, G., Blackburn, S., Bolch, C., RJ, L. (Eds.), Harmful Algal Blooms 2001. Intervovernmental Oceanographic Organisation of UNESCO, pp. 429-432.

Richardson, T.L., Pinckney, J.L., 2004. Monitoring of the toxic dinoflagellate Karenia brevis using gyroxanthin-based detection methods. J. Appl. Phycol. 16, 315-328.

doi:10.1023/B:JAPH.0000047788.31312.4f

Scholin, C.A., Doucette, G., Jensen, S., Roman, B., Pargett, D., Marin, R., Preston, C., Jones, W., Feldman, J., Everlove, C., Harris, A., Alvarado, N., Massion, E., Birch, J., Greenfield, D., 2009. Remote sensing of marine microbes, small invertebrates, harmful algae and biotoxins using the Environmental Sample Processor (ESP). Oceanography 22, 158-167. doi:10.5670/oceanog.2009.46.COPYRIGHT

Shutler, J.D., Davidson, K., Miller, P.I., Swan, S.C., Grant, M.G., Bresnan, E., 2012. An adaptive approach to detect high-biomass algal blooms from EO chlorophyll- a data in support of harmful algal bloom monitoring. Remote Sens. Lett. 3, 101-110. doi:10.1080/01431161.2010.538089

Spyrakos, E., González Vilas, L., Torres Palenzuela, J.M., Barton, E.D., 2011. Remote sensing chlorophyll a of optically complex waters (rias Baixas, NW Spain): Application of a regionally specific chlorophyll a algorithm for MERIS full resolution data during an upwelling cycle. Remote Sens. Environ. 115, 2471-2485. doi:10.1016/j.rse.2011.05.008 
Stumpf, R.P., Litaker, R.W., Lanerolle, L., Tester, P.A., 2008. Hydrodynamic accumulation of Karenia off the west coast of Florida. Cont. Shelf Res. 28, 189-213. doi:10.1016/j.csr.2007.04.017

Tillmann, U., Elbrächter, M., Krock, B., John, U., Cembella, A., 2009. Azadinium spinosum gen. et sp. nov. (Dinophyceae) identified as a primary producer of azaspiracid toxins. Eur. J. Phycol. 44, 6379. doi:10.1080/09670260802578534

Touzet, N., Davidson, K., Pete, R., Flanagan, K., McCoy, G.R., Amzil, Z., Maher, M., Chapelle, A., Raine, R., 2010. Co-occurrence of the West European (Gr.III) and North American (Gr.I) ribotypes of Alexandrium tamarense (Dinophyceae) in Shetland, Scotland. Protist 161, 370-84. doi:10.1016/j.protis.2009.12.001

Touzet, N., Franco, J.M., Raine, R., 2007. Characterization of nontoxic and toxin-producing strains of Alexandrium minutum (Dinophyceae) in Irish coastal waters. Appl. Environ. Microbiol. 73, 333342. doi:10.1128/AEM.02161-06

Vanhoutte-Brunier, A., Fernand, L., Ménesguen, A., Lyons, S., Gohin, F., Cugier, P., 2008. Modelling the Karenia mikimotoi bloom that occurred in the western English Channel during summer 2003. Ecol. Modell. 210, 351-376. doi:10.1016/j.ecolmodel.2007.08.025

Velo-Suárez, L., Reguera, B., González-Gil, S., Lunven, M., Lazure, P., Nézan, E., Gentien, P., 2010. Application of a 3D Lagrangian model to explain the decline of a Dinophysis acuminata bloom in the Bay of Biscay. J. Mar. Syst. 83, 242-252. doi:10.1016/j.jmarsys.2010.05.011

Whyte, C., Swan, S., Davidson, K., 2014. Changing wind patterns linked to unusually high Dinophysis blooms around the Shetland Islands, Scotland. Harmful Algae 39, 365-373.

doi:10.1016/j.hal.2014.09.006 


\section{Legends}

Figure1: The Asimuth domain illustrating the seaboard areas for which that models and risk assessments were developed.

Figure 2: An example of rapid parallel increase in both Dinophysis and DSP shellfish toxins (OA and DTXs) generated by an advective bloom in the Scottish Shetland Isles. The speed of increase in toxicity was sufficient, that weekly in situ monitoring did not prevent the harvesting of contaminated shellfish.

Figure 3: Example, predicted (modelled) Alexandrium fundyense distribution in the Gulf of Maine. 
Figure 1

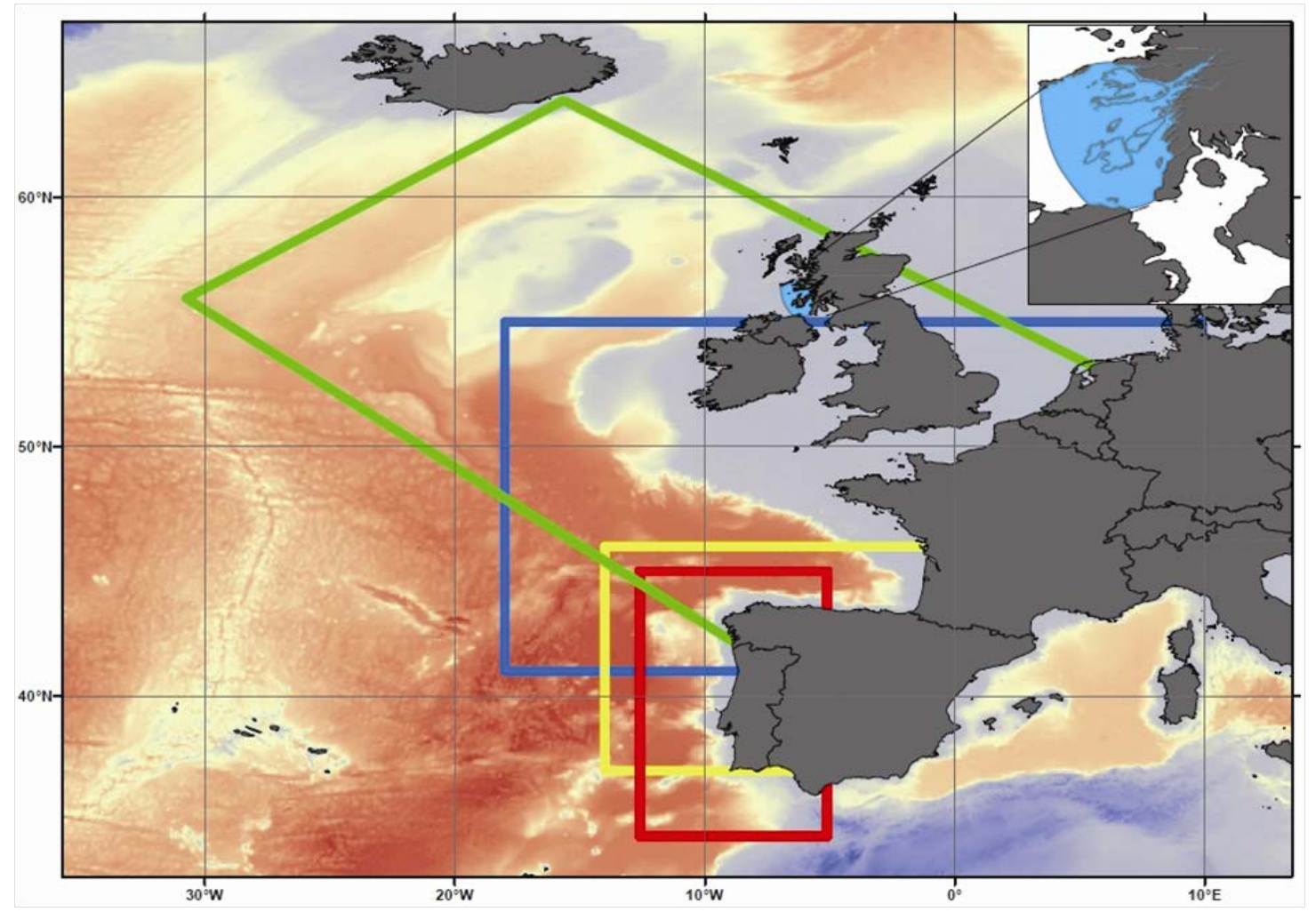


Figure 2
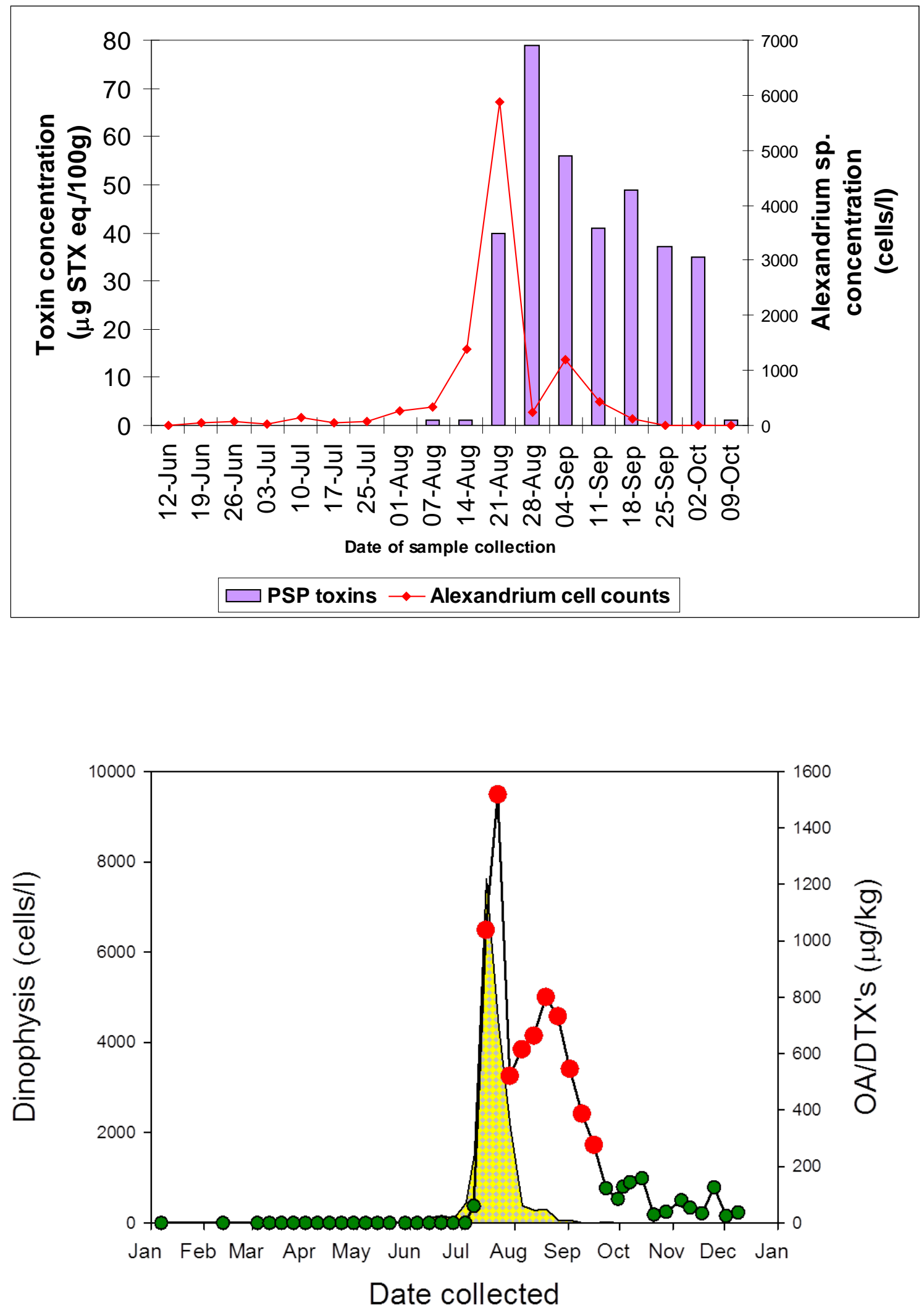
Figure 3

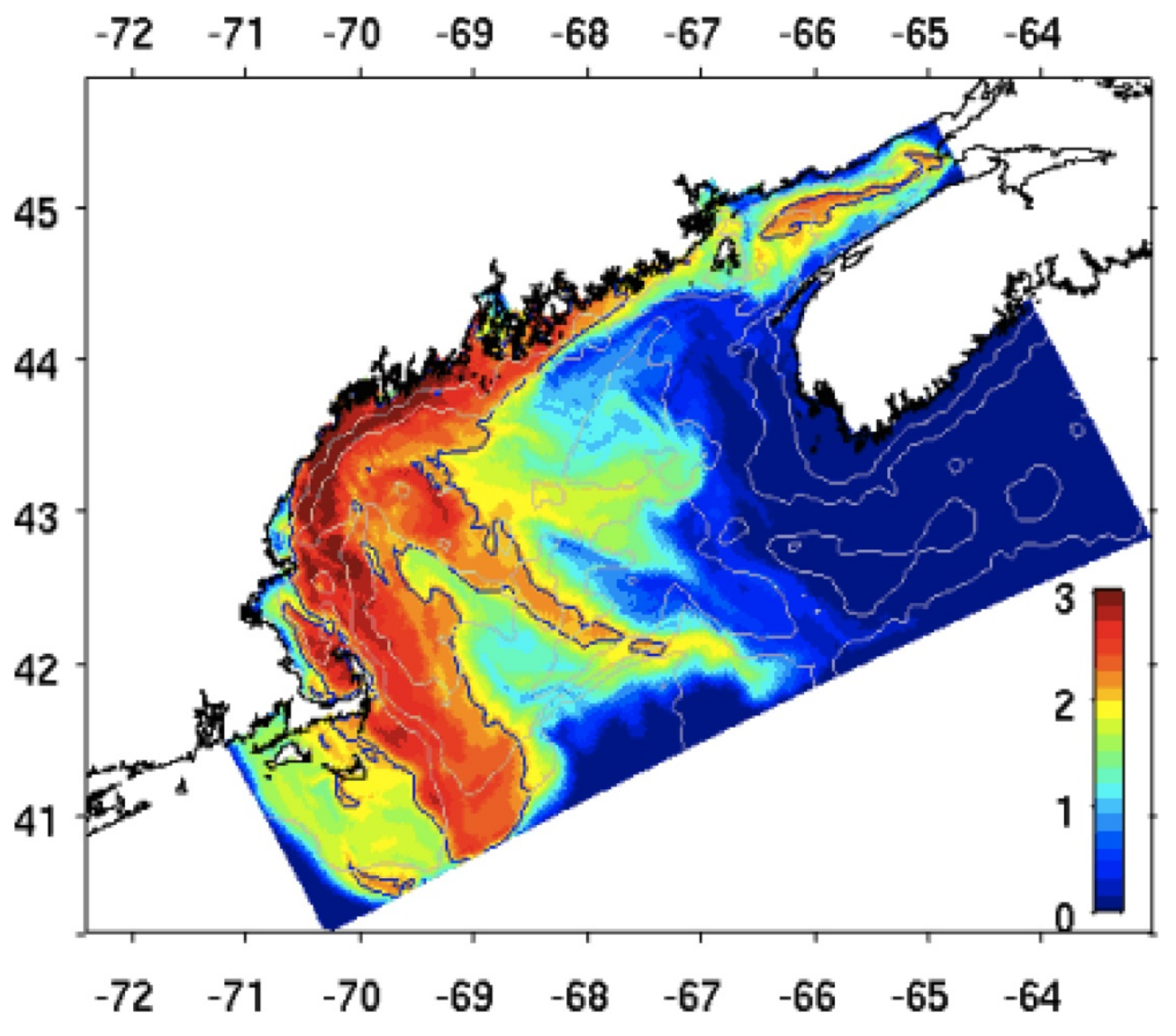

